\title{
Pathology of Myxosporea in marine fish culture
}

\author{
Pilar Alvarez-Pellitero, Ariadna Sitjà-Bobadilla \\ Instituto de Acuicultura Torre de la Sal (C.S.I.C.), E-12595 Ribera de Cabanes, Castellón, Spain
}

\begin{abstract}
A review of the pathogenic impact of Myxosporea in marine fish culture is presented. At least 11 species of Bivalvulida and 7 species of Multivalvulida have been described in marine or brackish fish kept in different culture systems. The pathological importance of these myxosporoses is discussed, and their potential importance with the growth of culture facilities is stressed.
\end{abstract}

KEY WORDS: Aquaculture - Myxosporea Pathology

\section{INTRODUCTION}

Myxosporea is a controversial group of parasites affecting mainly fish. Its taxonomical status is still to be revised in view of recent findings on myxosporean life cycles (Wolf \& Markiw 1984, El-Matbouli \& Hoffmann 1989). The most recent knowledge of Myxosporea important for freshwater fish was reviewed by ElMatbouli et al. (1992). These authors pointed out the difficulty in assessing the pathogenicity of Myxosporea and the economic losses they incur This is particularly true in mariculture, partly due to the scarcity of parasitological studies on cultured marine fish. Some information can be found in the reviews of Lom (1984) and Paperna (1991). Nevertheless, with the development of marine aquaculture, outbreaks of diseases due to Myxosporea are reported frequently, and some species may become a serious constraint for mariculture.

In this review, we present much of what is known of Myxosporea actually or potentially harmful for marine fish under culture conditions. We compile our own findings from a long-term parasitological survey of marine fish in different culture systems, as well as other reports from the literature.

\section{MYXOSPOROSES CAUSED BY BIVALVULIDA}

Cases of Bivalvulida in cultured marine or brackish fish are listed in Table 1 . They have been reported in different culture systems, including ponds, intensive and semi-intensive farms, and cages in the sea.

\section{Ceratomyxa spp.}

Ceratomyxa spp. have been reported from different cultivable fish of the families Serranidae, Sparidae, Mugilidae, etc. (Lubat et al. 1989, Paperna 1991. Alvarez-Pellitero \& Sitjà-Bobadilla 1993, SitjàBobadilla \& Alvarez-Pellitero 1993a). Two of them, Ceratomyxa labracis and $C$. diplodae, parasitize Mediterranean sea bass Dicentrarchus labrax in wild and culture conditions (Sitjà-Bobadilla \& AlvarezPellitero 1993a). No external clinical signs were usually found, but histopathological damage was detected in the gall bladder by light and electron microscopy, mainly consisting of vacuolation, deformation or even necrosis of epithelial cells (Figs. 1 \& 2). Thickening and inflammation of the subepithelial connective tissue (Fig. 3) and damage to the neighbouring pancreatic tissue (Fig. 4) were also observed. Trophozoites appeared frequently lining the epithelium, closely attached to the cell surface or even forming invaginations in it.

As in other ceratomyxoses, spread of the parasite to other organs was observed in very intense infections. Prevalence of Ceratomyxa labracis reached $42 \%$ in cultured fish and intensities were very high in some individuals. Stress situations, such as starvation, seem to 
Table 1. Bivalvulida parasites of cultured marine fish

\begin{tabular}{|c|c|c|c|}
\hline Species & Host & Culture system & Source \\
\hline $\begin{array}{l}\text { Ceratomyxa labracis } \\
\text { C. diplodae. }\end{array}$ & Dicentrarchus labrax & $\begin{array}{l}\text { Open systems, farms \& } \\
\text { research facilities on the } \\
\text { Mediterranean coast of Spain }\end{array}$ & $\begin{array}{l}\text { Alvarez-Pellitero \& } \\
\text { Sitjà-Bobadilla (1993); } \\
\text { Sitjà-Bobadilla \& } \\
\text { Alvarez-Pellitero (1993a) }\end{array}$ \\
\hline $\begin{array}{l}\text { Sphaerospora } \\
\text { testicularis }\end{array}$ & Dicentrarchus labrax & $\begin{array}{l}\text { Research facilities on the } \\
\text { Mediterranean coast of Spain }\end{array}$ & $\begin{array}{l}\text { Sitjà-Bobadilla \& } \\
\text { Alvarez-Pellitero }(1990,1993 \mathrm{~b}, \mathrm{c})\end{array}$ \\
\hline S. dicentrarchi & Dicentrarchus labrax & $\begin{array}{l}\text { Open systems, farms \& } \\
\text { research facilities on the } \\
\text { Mediterranean coast of Spain }\end{array}$ & $\begin{array}{l}\text { Sitjà-Bobadilla \& } \\
\text { Alvarez-Pellitero }(1992,1993 b, c)\end{array}$ \\
\hline S. epinepheli & $\begin{array}{l}\text { Epinephelus } \\
\text { malabaricus }\end{array}$ & $\begin{array}{l}\text { Cages in estuarine waters } \\
\text { of South Thailand }\end{array}$ & Supamattaya et al. $(1990,1991)$ \\
\hline S. inregularis & Pleuronectes platessa & Scottish waters & Mackenzie et al. (1976) \\
\hline Sphaerosporidae & $\begin{array}{l}\text { Sparus aurata } \\
\text { Mugilidae }\end{array}$ & $\begin{array}{l}\text { Open semi-intensive systems } \\
\text { on South Atlantic coast \& Ebro } \\
\text { River delta in Mediterranean } \\
\text { waters, Spain }\end{array}$ & Sitja-Bobadilla et aì. (1992) \\
\hline Zschokkella mugilis & Mugilidae & $\begin{array}{l}\text { Open semi intensive system } \\
\text { in River Ebro delta, Spain }\end{array}$ & $\begin{array}{l}\text { Sitjà-Bobadilla \& } \\
\text { Alvarez-Pellitero (1993d) }\end{array}$ \\
\hline Myxidium sp. & Sparus aurata & Open farms in Southern Cyprus & Diamant (1992) \\
\hline Myxobolus spp. & Mugilidae & Ponds in Israel & Paperna (1991) \\
\hline Myxobolus buri & Seriola quinqueradiata & Japanese farms & Egusa (1985) \\
\hline
\end{tabular}

favour the appearance of ceratomyxosis (AlvarezPellitero \& Sitjà-Bobadilla 1993).

\section{Sphaerospora spp}

Different Sphaerospora spp. have been recently found in cultured marine fish, mainly in Mediterranean waters.

Dicentrarchus labrax harbours 2 species, each of them giving an example of a different type of infection (Sitjà-Bobadilla \& Alvarez-Pellitero 1990, 1992, $1.993 b, c)$.

Sphaerospora dicentrarchi is a histozoic systemic parasite in almost every organ of the host, though its preferred locations are the connective and muscular tissues of the gall bladder. (Fig. 5) and intestine. Prevalences reach $100 \%$ in wild fish and $70.5 \%$ in cul.tured fish (Sitjà-Bobadilla \& Alvarez-Pellitero 1993c). This Myxosporea seems to be harmless, except in massive infections, in which extensive areas of the organs appear invaded with the subsequent destruction of tissues, especially in kidney, pancreas (Figs. 6 to 8) and testes. Nevertheless, no serious cellular reaction was detected by light microscopy, apart from some leucocytic proliferation or macrophages engulfing spores.

Sphaerospora testicularis is usually a coelozoic para- site in the seminiferous tubules, and does not provoke any cellular host reaction or any apparent harm in slight infections (Fig 9). In massive infections, the parasite can invade neighboring testicular tissues, provoking the destruction of testicular areas (Fig. 10). TEM observations (Fig. 11) showed myxosporean stages in the lumen of affected tubules, whereas spermatogonia and Sertoli cells adjacent to destroyed areas appeared vacuolated, with disorganized organelles and hypertrophic nuclei. Interstitial tissue was enlarged due to the abundance of myoid cells. Moreover, in massive infections the parasite spreads beyond the lumen, towards neighbouring testicular tissue and the serosa of adjacent organs, generating an important cellular host reaction. The affected serosa was hypertrophied (Fig. 12) and leucocytic infiltration, mainly consisting of granulocytes, was observed. In these cases of massive infections, gross signs of disease may be observed, consisting of abdominal swelling due to the accumulation of ascites and hypertrophy and hyalinization of testes, with subsequent rise of the gonadosomatic index. At the end of the spawning season, the massively infected testes exhibited most of the tubular lumen being occluded by encapsulated parasites, with a fibrotic host reaction (fibroblast-like cells, desmosomes, fibrocytes and collagen fibers). Degenerated spores and vacuolated or necrotic deposits were observed (Figs, 13 \& 14). Therefore, the infection 


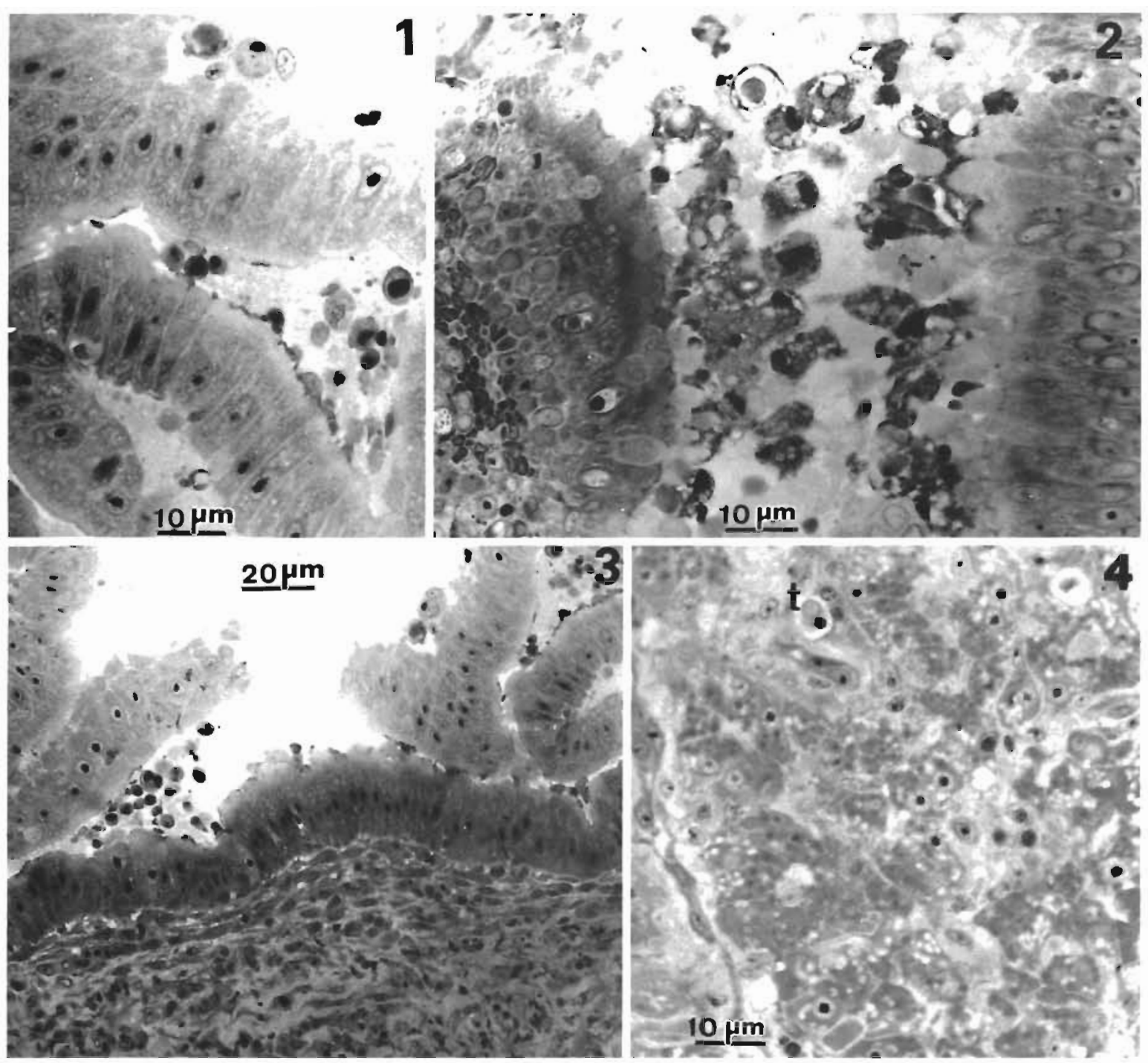

Figs. 1 to 4 . Sections of Dicentrarchus labrax tissues infected by Ceratomyxa spp. Figs. 1 to 3 . Parasitized gall bladders, showing vacuolation (Fig. 1) necrosis, sloughing of epithelial cells together with trophozoites of the myxosporean (Fig. 2), and thickening of the subepithelial connective tissue (Fig. 3). Fig. 4. Pancreatic tissue neighbouring gall bladder, showing cellular vacuolation and destruction; t: trophozoite. Staining: toluidine blue

caused by $S$. testicularis is considered to represent parasitic castration.

During the spawning period, parasitic stages are released with the sperm. Intensity was usually low at the beginning of spermiation period, when early trophozoites were the main stage observed, and increased progressively while the parasite gradually developed. Infection prevalence also showed a progressive increase throughout the spawning period (SitjàBobadilla \& Alvarez-Pellitero 1993c).

The other Sphaerosporidae from marine or estuarine cultured fish are kidney parasites.

Sphaerospora epinepheli produced heavy infections in cage-cultured grouper Epinephelus malabaricus from estuarine areas of Southern Thailand. Necrosis of renal tubular epithelium and peritubular fibrosis were observed in many tubules filled with masses of spores and developing stages of the parasite. Renal corpuscles were also affected, and some of them were necrotic and shrunken (Supamattaya et al. 1990, 1991).

Spaherospora irregularis (syn. of Ortholinea irregularis according to Arthur \& Lom 1985) was reported in plaice Pleuronectes platessa from Scottish waters with high infection rates (up to $70 \%$ ) (Mackenzie et al. 1976).

Another renal member of the Sphaerosporidae, previously reported as Sphaerospora sp. (Sitjà-Bobadilla et al. 1992), is now considered a probable new genus 


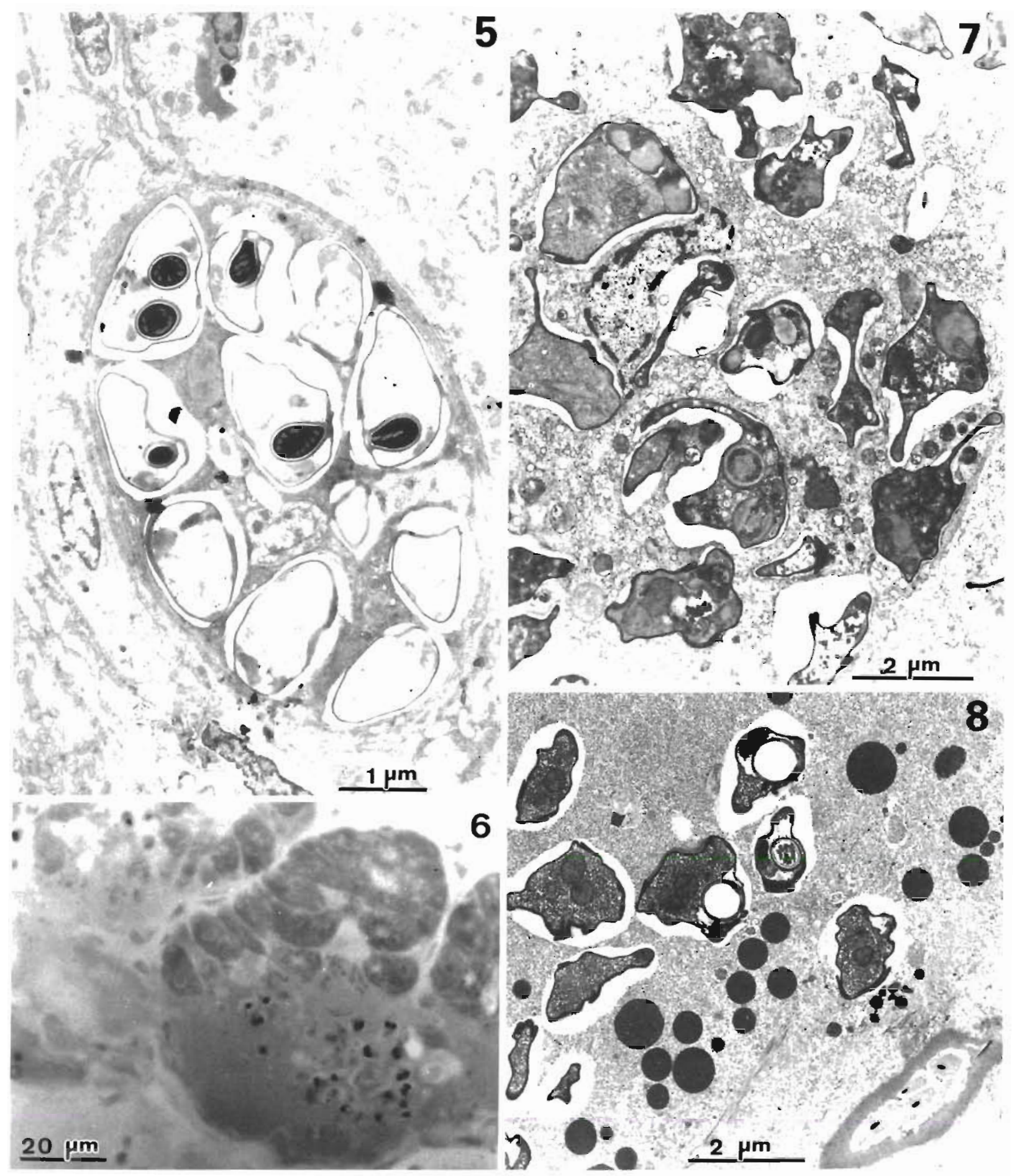

Figs. 5 to 8 . Sections of Dicentrarchus labrax tissues infected by Sphaerospora dicentrarchi. Fig. 5 . TEM detail of a bag-Jike group of spores in the intestinal wall, with light host reaction. Figs. 6 to 8 . LM (Fig. 6) and TEM (Figs. 7 \& 8 ) images of infected pancreas Note degeneration and destruction of areas invaded by the myxosporean. LM staining: toluidine blue

Figs. 9 to 14. Sections of Dicentrarchus Labrax testes infected by Sphaerospora testicularis. Fig. 9. LM view of a light infection Note the presence of trophozoites ( $t$ ) in the tubule lumen without apparent host reaction. Figs. 10 \& 11. LM (Fig. 10) and TM (Fig 11) images of heavily infected testes. Note destruction of germinal tissue and enlargement of interstitial tissue. sg: residual spermotogonia; sp: spore of the myxosporean. Fig. 12. LM image of a massively infected testis with invasion of serosa, appearing hypertrophied, with an inflammatory reaction. Figs. 13 \& 14 . Host reaction against the myxosporean at the end of the spawning season, showing residual spores inside a fibrotic capsule under TEM (Fig. 13) and LM (Fig 14) LM stainıng tolurdıne blue 

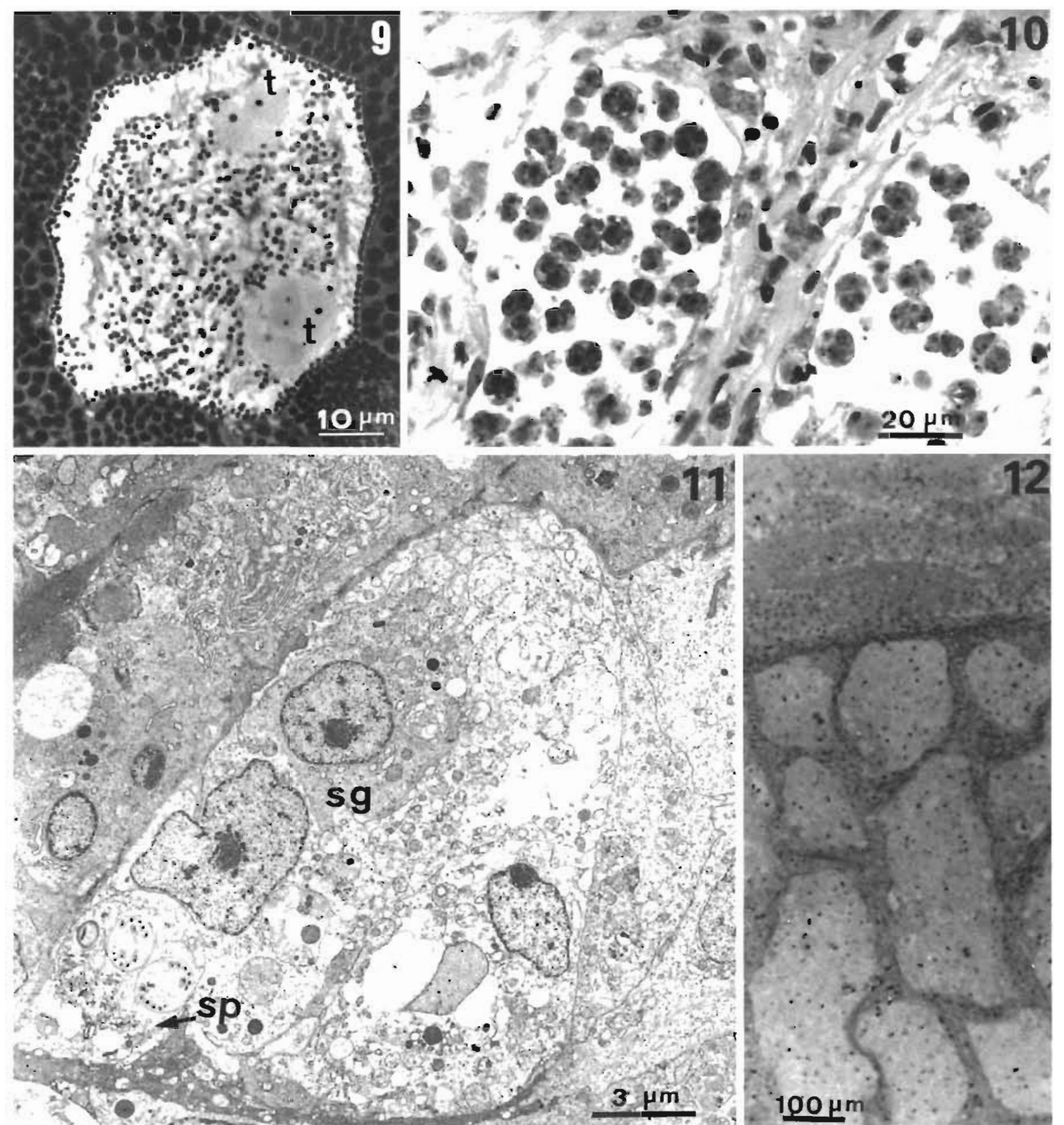

0

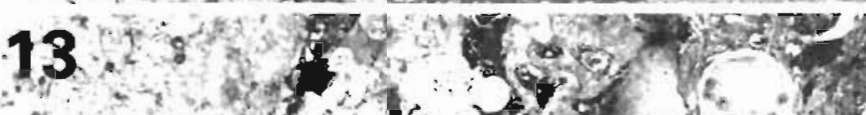

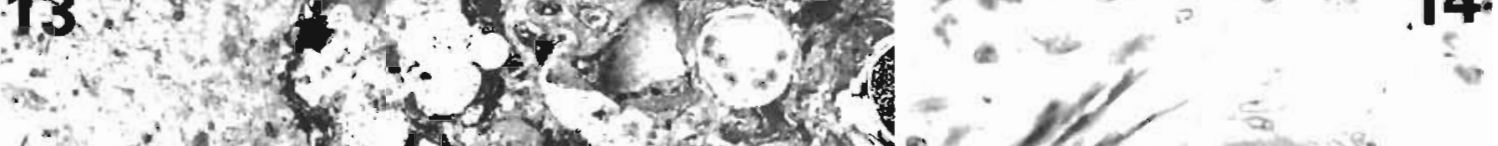

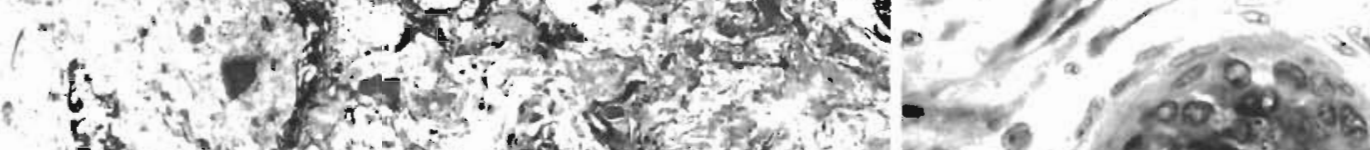

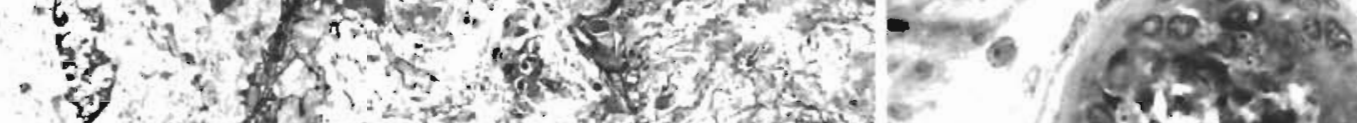

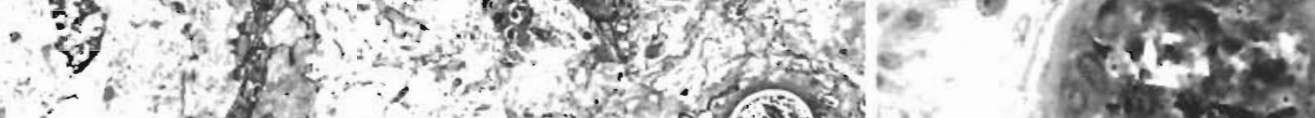

$\therefore$ (n) 
Table 2. Multivalvulida parasites of cultured marine fish

\begin{tabular}{|c|c|c|c|}
\hline Species & Host & Culture system & Source \\
\hline \multirow[t]{3}{*}{ Kudoa thyrsites } & Coryphaena hyppurus & Sea cages in Albany, Western Australia & Langdon (1991) \\
\hline & Oncorhynchus spp. & $\begin{array}{l}\text { Hatcheries \& farms in British Columbia, } \\
\text { Canada }\end{array}$ & Kabata \& Whitaker (1989) \\
\hline & Salmo salar & $\begin{array}{l}\text { Smolts transferred to sea water in } \\
\text { Washington, USA }\end{array}$ & Harrell \& Scott (1985) \\
\hline$K$ K. amamiensis & Seriola quinqueradiata & Sea cages in Japan & Egusa \& Nakajima $(1978,1980)$ \\
\hline K. pericardialis & Seriola quinqueradiata & Sea cages in Japan & Nakajima \& Egusa (1978) \\
\hline K. iwatai & $\begin{array}{l}\text { Pagrus major } \\
\text { Oplegnathus punctatus }\end{array}$ & Sea cages in Japan & Egusa \& Shiomitsu (1983) \\
\hline K. shiomitsui & Takifugu rubripes & Sea cages in Japan & Egusa \& Shiomitsu (1983) \\
\hline Kudoa sp. & Sparus aurata & Mediterranean waters in Israel & Paperna (1982) \\
\hline $\begin{array}{l}\text { Fiexacapsuid } \\
\text { neothunni(?) }\end{array}$ & $\begin{array}{l}\text { Laieoiabrax japonicus } \\
\text { Oplegnathus fasciatus } \\
\text { Seriola quinqueradiata }\end{array}$ & Fish farm in japan & Yasunaga et al. (1981) \\
\hline
\end{tabular}

following TEM studies demonstrating the presence of several sporoplasmic cells (unpubl. data). It parasitizes gilthead sea bream Sparus aurata and mugilids cultured in semi-extensive conditions. Prevalence may reach $80 \%$ and intensities were high enough to cause serious damage to the kidney. Glomerular destruction, haemorrhagia and leucocytic infiltration were the main histopathological effects (Figs. 15 \& 16). An outbreak was observed in gilthead sea bream, in which dermal ulcers were seen in $20 \%$ of 18 mo old

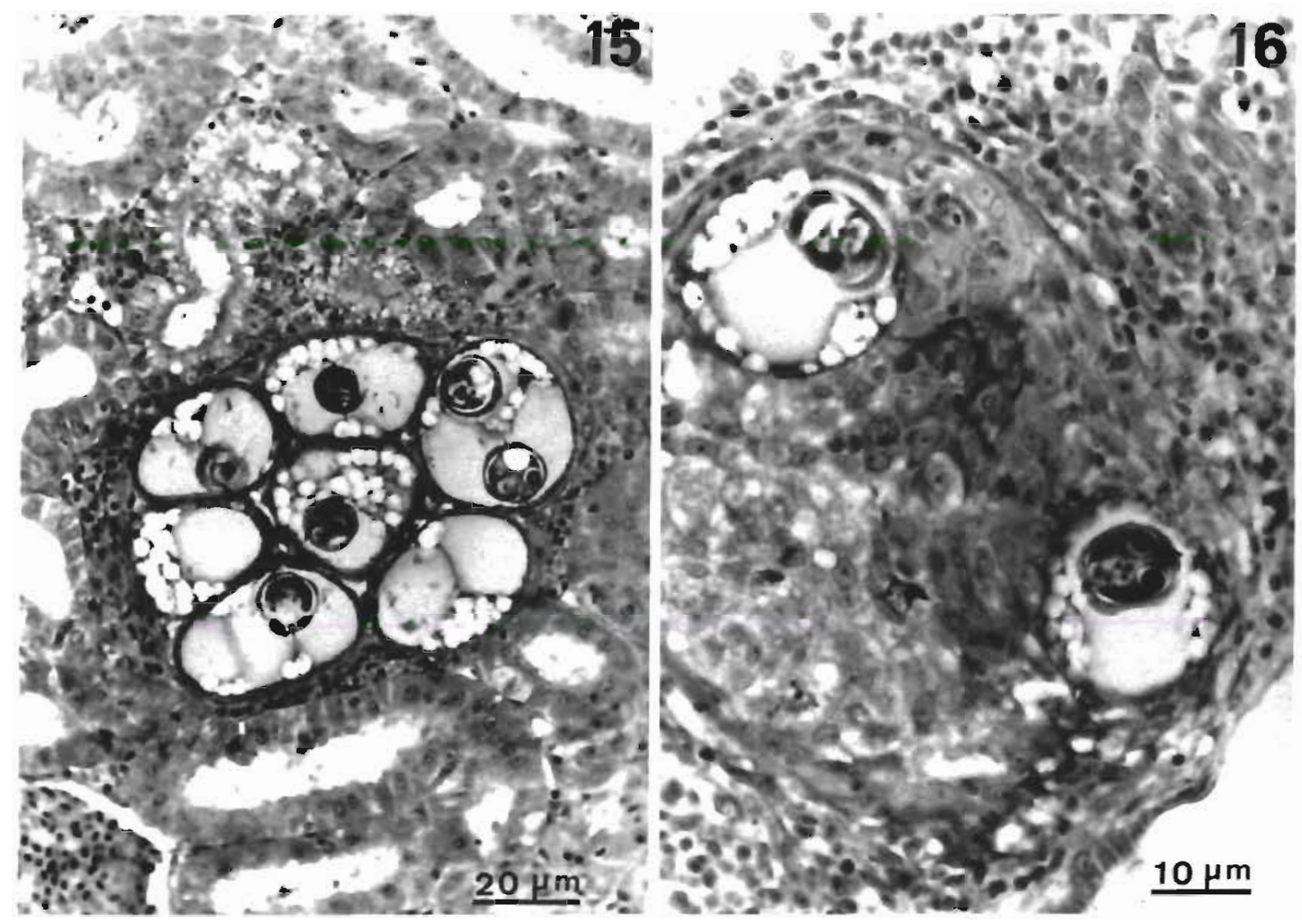

Figs. 15 \& 16. Sections of Liza aurata kidney infected by a sphaerosporid. Fig. 15. Detail of a glomeruli harboring disporoblasts, surrounded by a thin capsule and a slight leucocytic infiltration. Tubuli also appear damaged. Fig. 16. Parasitic stages inside a granuloma. Staining: toluidine blue 


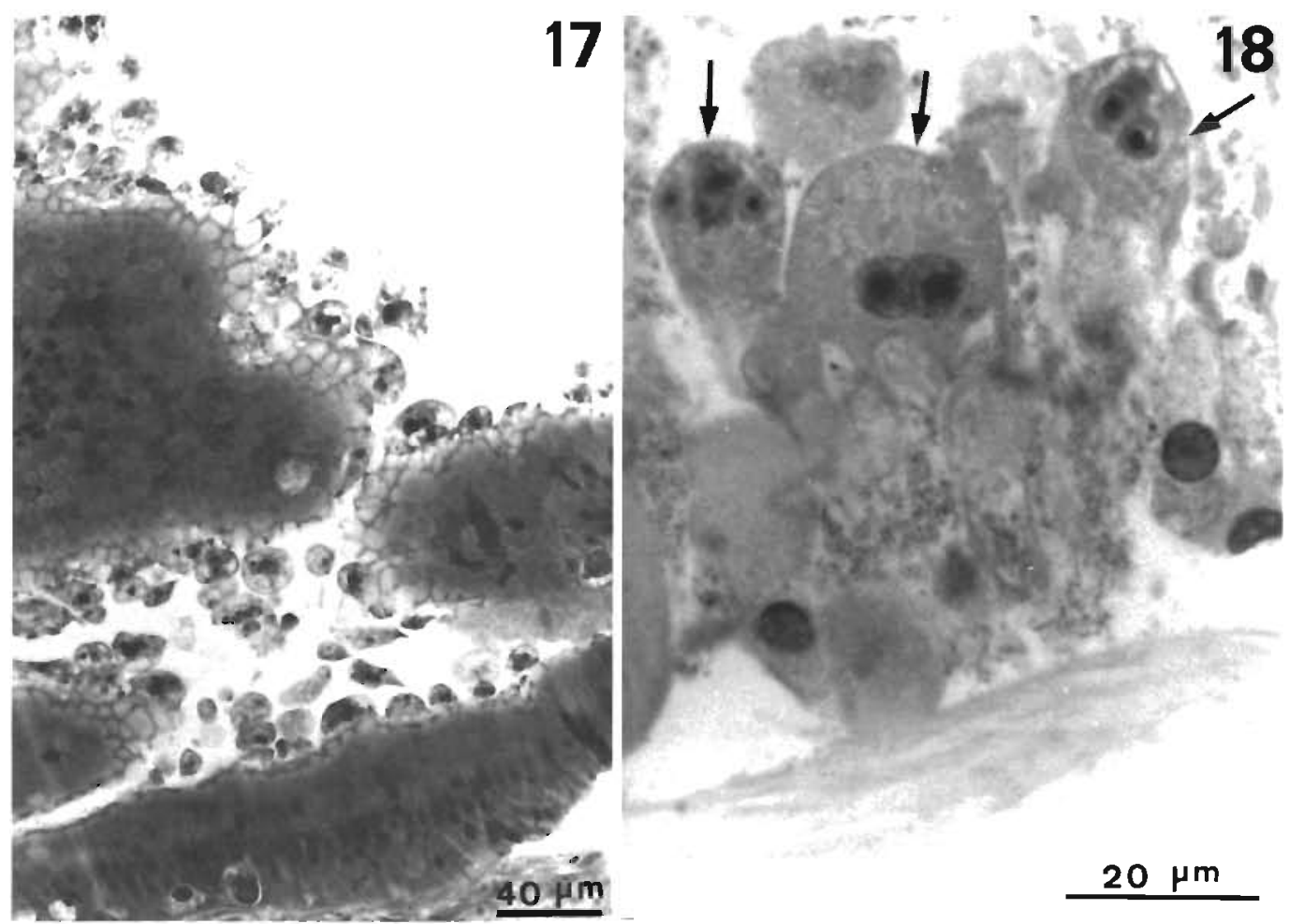

Figs. 17 \& 18. Sections of Liza saliens gall bladders infected by Zschokella mugilis. Fig. 17 Gall bladder epithelium lined with parasitic stages. Fig. 18. Very affected epithelium showing cellular vacuolation, sloughing and destruction, together with parasitic stages (arrows). Staining: toluidine blue

fish. All ulcerated fish necropsied harboured this Sphaerosporidae in the kidney and dermal ulcers (Sitjà-Bobadilla et al. 1992).

\section{Zschokkella sp.}

Zschokkella mugilis was found in the gall bladder of mugilids captured in the wild (River Ebro delta, Spain) and maintained in a semi-intensive open system. Histopathological damage consisted of vacuolation, deformation, or even necrosis of epithelial cells. Trophozoites and sporoblasts appeared frequently lining the epithelium, usually forming invaginations in it (Figs. $17 \& 18$ ). Prevalence was about $70 \%$ and intensity was very high in some fish, so the infection probably contributed to the mortalities observed in some fish groups (Sitjà-Bobadilla \& Alvarez-Pellitero 1993d).

\section{Other Bivalvulida}

Other occasional findings of myxosporeans in cultured marine fish are those of Myxidium sp. in the intestinal mucosa of Sparus aurata suffering moderate mortalities (Diamant 1992), Myxobolus sp. in appar- ently healthy mullets (Paperna 1991) and Myxobolus buri in the brain of farmed Japanese yellowtails Seriola quinqueradiata (Egus 1985).

\section{MYXOSPOROSES DUE TO MULTIVALVULIDA}

Reported cases of Multivalvulida in cultured marine fish are mainly from sea cage cultures and are listed in Table 2.

\section{Kudoa spp.}

Several members of Kudoa have been reported amongst the main pathogens of different cultured marine fish, particularly in cage cultures. They produce typical focal lesions (Fig. 19), which are often the cause of the myoliquefactive postmortem condition known as 'milky flesh'. Kudoa thyrsites, one of the species parasitizing Pacific hake Merluccius productus in the wild (Kabata \& Whitaker 1986), has also been reported in different fish in culture conditions, such as mahi mahi Coryphaena hippurus in sea cages at Albany, western Australia (Langdon 1991), Pacific salmon Oncorhynchus spp. in different hatcheries and farms of British 


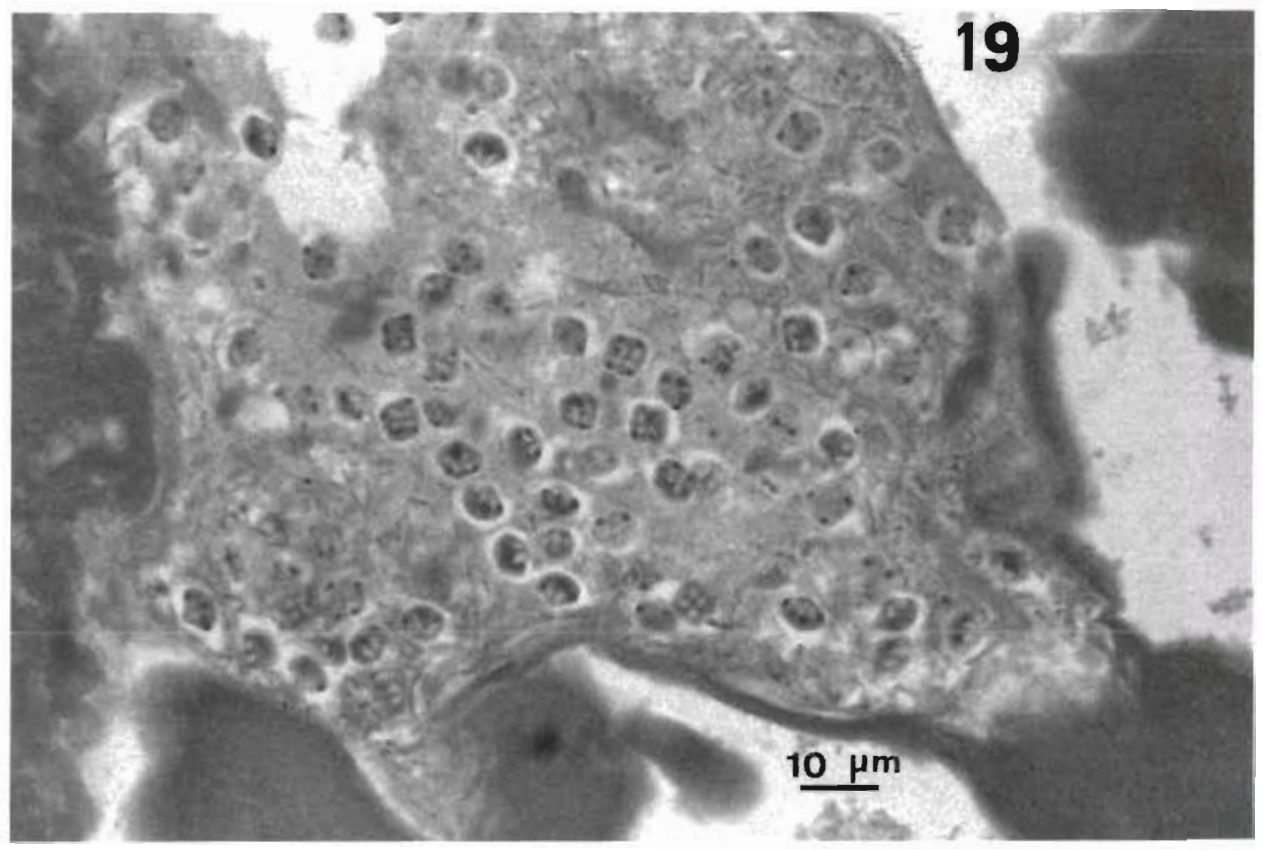

Fig 19. Section of muscle of hake Meriuccius merluccius infected by Kudoa sp. Staining: H\&E
Columbia, Canada (Kabata \& Whitaker 1989), and Atlantic salmon Salmo salar after transferring to sea water in Washington, USA (Harrell \& Scott 1985). Apart from dorsal musculature lesions, consisting of a characteristic multifocal intracellular infection with associated inflammatory reaction, inflammatory foci were observed in pericardium and myocardium and foci of coagulative hepatocellular necrosis in the liver and renal intertubular tissue of $C$. hippurus. Some salmonids also showed infection of cardiac muscle

Occasional infections by Kudoa sp. have also been recorded in cultured Sparus aurata from the Mediterranean Sea in France and lsrael. The myxosporean. was located in glomeruli and mesentery or serosa, though damage was only evident in the former, whose capillaries could become obstructed or completely obliterated (Paperna 1982)

Kudoases have also been reported from different fish cultured in sea cages on Japanese coasts. Kudoa amamiensis parasitizes skeletal muscle of yellowtail. Serjola quinqueradiata (Egusa \& Nakajima 1978. 1980). Kudoa pericardialis was found in the pericardial cavity of the same host (Nakajima \& Egusa 1978). Sea bream Pagrus major and Oplegnatus punctatus were parasitized by Kudoa iwatai in the lateral musculature. whereas Kudoa shiomitsui parasitizes the pericardial cavity and ventricle of Takifugu rubripes (Egusa \& Shiomitsu 1983).

Infected wild fish from neighboring waters may act as reservoir hosts for cage-cultured fish. This has been suggested for yellowtail infected with Kudoa amamiensis, since coral fish from the same area were also found parasitized by trophozoites of the parasite. Also, several clupeoid fish from Australian waters could be the source of $K$. thyrsites for cultured Coryphaena hypurus (Langdon et al. 1992), and the usual hosts of Kudoa spp. could transmit the parasite to certain salmonids, with subsequent implications for salmon stocks.

\section{Hexacapsula sp}

A myxosporean reminiscent of Hexacapsula neothunni was reported by Yasunaga et al. (1981) as a cause of mortalities of cultured sea bass Lateolabrax japonicus, and was also present in cultured knifejaw Oplegnathus fasciatus and yellowtail. Seriola quinqueradiata.

\section{CONCLUSION}

The data summarized above on Myxosporea of cultured marine fish reveal the actual and potential threat of these infections in aquaculture. Some species are a real danger to cultured stocks, e.g. Sphaerospora testicularis decreases the reproduction rate of sea bass either by destroying the germinative tissue (SitjàBobadilla \& Alvarez-Pellitero 1993b) or by feeding on spermatozoa (Sitjà-Bobadilla \& Alvarez-Pellitero 1993e); some Kudoa infections can detract from the marketability of fish products, although there is no human health risk (see Langdon et al. 1992); this could also be the case for the Sphaerospora-like infection in sea bream. Other Myxosporea infections, with no clin- 
ical signs or serious mortalities, but clear histopathological damage, can become a potential threat under stress conditions or may immunodepress the host, hence favouring the entrance and establishment of other pathogens.

In addition, other Myxosporea hitherto found in different wild fish may become of concern with the growth in culture facilities. In sea cages, where the transmission of Myxosporea from the same or other host fish species cannot be ignored, wild fish may be a direct source or alternate reservoir host of infections.

Although the pathogenic effects of some myxosporean species have been extensively described, little is known about the transmission and pathogenic mechanisms of these organisms, or how they challenge the fish immune system. Such knowledge might help in determining more rational and effective prophylactic measures, which the current fish culture industry is so devoid of.

Acknowledgements. This work was supported in part by a grant (FPI) from the Ministerio de Educación y Ciencia of Spain to A. Sitjà-Bobadilla and the project MAR/89/0557 from the Comisión Interministeral de Ciencia y Tecnología (CICYT) of Spain.

\section{LITER ITURE CITED}

Alvarez-Pellitero, P., Sitja-Bobadilla, A. (1993). Population dynamics of Ceratomyxa spp. (Protozoa: Myxosporea) infection in wild and cultured sea bass, Dicentrarchus labrax (L.) from the Spanish Mediterranean area. J. Fish Biol. 42: $889-901$

Arthur, J. R., Lom, J. (1985). Sphaerospora araii n. sp. (Myxosporea: Sphaerosporidae) from the kidney of a longnose skate (Raja rhina Jordan and Gilbert) from the Pacific Ocean off Canada. Can. J. Zool. 63: 2902-2906

Diamant, A. (1992). A new pathogenic histozoic Myxidium (Myxosporea) in cultured gilt-head sea bream Sparus aurata. Bull. Eur. Ass. Fish Pathol. 12: 64-66

Egusa, S. (1985). Myxobolus buri sp. n. (Myxosporea: Bivalvulida) parasitic in the brain of Seriola quinqueradiata Temmick et Schlegel. Fish Pathol. 19:239-244

Egusa, S., Nakajima, K. (1978). Kudoasis of cultured yellowtail. Fish Pathol. 13: 1-7

Egusa, S., Nakajima, K. (1980). Kudoa amamiemsis n. sp. (Myxosporea: Multivalvulida) found in cultured yellowtails and wild damselfishes from Amami-Ohshima and Okinawa, Japan. Bull. Jap. Soc. scient. Fish. 46: $1193-1198$

Egusa, S., Shiomitsu, T (1983). Two new species of the genus Kudoa (Myxosporea: Muyltivalvulida) from marine cultured fishes in Japan. Fish Pathol. 18: 163-171

El-Matbouli, M., Fischer-Scherl, Th., Hoffmann, R. W. (1992). Present knowledge of the life cycle, taxonomy, pathology and therapy of some Myxosporea important for freshwater fish. Ann. Rev. Fish Dis. 2: 367-402

El-Matbouli, M. Hoffmann, R. W. (1989). Experimental transmission of two Myxobolus spp. developing bisporogeny via tubificid worms. Parasitol. Res. 75: 461-464
Harrell, L. W., Scott, T M. (1985). Kudoa thyrsites (Gilchrist) (Myxospored: Multivalvulida) in Atlantic salmon (Salmo salar L.). J. Fish Dis. 8: 329-332

Kabata, Z., Whitaker, D. J. (1986). Distribution of two species of Kudoa (Myxozoa: Multivalvulida) in offshore population of the Pacific hake, Merluccius productus (Ayres 1855). Can. J. Zool. 64: 2103-2110

Kabata, Z., Whitaker, D. J. (1989). Kudoa thyrsites (Gilchrist, 1924) (Myxozoa) in the cardiac muscle of Pacific salmon (Oncorhynchus spp.) and steelhead trout (Salmo gairdneri). Can. J. Zool. 67: 341-342

Langdon, J. S. (1991). Myoliquefaction post-mortem ('milky flesh') due to Kudoa thyrsites (Gilchrist) (Myxosporea Multivalvulida) in mahi mahi, Coryphaena hippurus L. J. Fish. Dis. 14: 45-54

Langdon, J. S., Thorne, T., Fletcher, W. J. (1992). Reservoir hosts and new clupeoid host records for the myoliquefactive myxosporean parasite Kudoa thyrsites (Gilchrist). J. Fish. Dis. 15: 459-471

Lom, J. (1984). Diseases caused by Protistans. In: Kinne, O. (ed.) Diseases of marine animals, Vol. IV Part I Biologische Anstalt Helgoland, Hamburg, p. 114-168

Lubat, J., Radujkovic, B., Marques, A., Bonix, G. (1989). Prasites des poissons marins du Montenegro Myxosporidies. Acta Adriatica 30:31-50

MacKenzie, K., McVicar, A. H., Waddell, I. F. (1976). Some parasites of plaice, Pleuronectes platessa L. in three different farm environments. Scott. Fish. Res. Rep. 4: 1-14

Nakajima, K., Egusa, S. (1978). Kudoa pericardialis n. sp (Myxosporidea: Chloromyxidae) from cultured yellowtail, Seriola quinqueradiata Temminck et Schlegel. Bull. Jap. Soc. scient. Fish. 44:117-120

Paperna, I. (1982). Kudoa infection in the glomeruli, mesentery and peritoneum of cultured Sparus aurata L. J Fish Dis. 5: $539-543$

Paperna, I. (1991). Diseases caused by parasites in the aquaculture of warm water fish. Ann. Rev. Fish Dis. 1: 155-194

Sitjà-Bobadilla, A., Alvarez-Pellitero, P. (1990). Sphaerospora testicularis sp. nov. (Myxosporea: Sphaerosporidae) in wild and cultured sea bass, Dicentrarchus labrax (L.), from the Spanish Mediterranean area. J. Fish Dis. 13: 193-203

Sitjà-Bobadilla, A., Alvarez-Pellitero, P. (1992). Light and electron microscopic description of Sphaerospora dicentrarchi n. sp. (Myxosporea: Sphaerosporidae) from wild and cultured sea bass (Dicentrarchus labrax L.). J. Protozool. 39: 273-281

Sitjà-Bobadilla, A., Alvarez-Pellitero, P. (1993a). Light and electron microscopic description of Ceratomyxa labracis $\mathrm{n}$. sp. and redescription of C. diplodae (Myxosporea: Bivalvulida) from wild and cultured Mediterranean sea bass (Dicentrarchus labrax L.) (Teleostei: Serranidae) System. Parasitol. (in press)

Sitjà-Bobadilla, A., Alvarez-Pellitero, P. (1993b). Pathologic effects of Sphaerospora dicentrarchi Sitjà-Bobadilla et A.lvarez-Pellitero, 1990 (Myxosporea: Bivalvulida), parasitic of Mediterranean sea bass (Dicentrarchus labrax L.) (Teleostei Serranidae), and the cell mediated immune reaction: a light and electron microscopic study. Parasitol. Res. 79: 119-129

Sitjà-Bobadilla, A., Alvarez-Pellitero, P. (1993c). Population dynamics of Sphaerospora dicentrarchi Sitjà-Bobadilla et Alvarez-Pellitero, 1992 and S. testicularis Sitjà-Bobadilla et Alvarez-Pellitero, 1990 (Myxosporea: Bivalvulida) infections in wild and cultured Mediterranean sea bass (Dicentrarchus labrax L.). Parasitology 106: 39-45

Sitjà-Bobadilla, A., Alvarez-Pellitero, P. (1993d). Zschokkella mugilis n. sp. (Myxosporea: Bivalvulida) from mullets 
(Teleostei: Mugilidae) of Mediterranean waters: light and electron microscopic description. J. eukaryot. Microbiol 40: in press

Sitjà-Bobadilla, A., Alvarez-Pellitero, P. (1993e). Uitrastructural and cytochemical observations on the sporogenesis of Sphaerospora testicularis (Protozoa: Myxosporea) from Mediterranean sea bass, Dicentrarchus labrax (L.). Eur. J. Protistol. 29: 219-229

Sitjà-Bobadilla, A., Franco-Sierra, A., Alvarez-Pellitero, P. (1992). Sphaerospora (Myxosporea: Bivalvulida) infection in cultured gilt head sea bream, Sparus aurata L.. a preliminary report. J. Fish Dis. 15: 339-343

Supamattaya, K., Fischer-Scherl, Th., Hoffmann, R. W., Boonyaratpalin, S. (1990). Renal sphaerosporosis in cul-

Responsible Subject Editor: W. Körting, Hannover, Germany tured grouper Ephinephelus malabaricus. Dis. aquat. Org. 8: $35-38$

Supamattaya, K., Fischer-Scherl, Th., Hoffmann, R. W., Boonyaratpalin, S. (1991). Sphaerospora epinepheli n. sp (Myxosporea: Sphaerosporidae) observed in grouper (Epinephelus malabaricus). J. Protozool. 38: 448-454

Wolf, K., Markiw, M. E. (1984). Biology contravenes taxonomy in the Myxozoa: new discoveries show alternation of invertebrate and vertebrate hosts. Science 225: 1449-1452

Yasunaga, N., Hatei, K., Ogawa, S., Yasumoto, S. (1981). An unknown myxozoa found in brain of cultured sea bass, Lateolobrax japonicus and cultured Japanese striped knifejaw, Oplegnatus fasciatus (Japan.). Fish Pathol. 16 $51-54$

Manuscript first received: February 23, 1993

Revised version accepted: July 22, 1993 